Law Eु Social Inquiry

Volume 34, Issue 4, 1017-1037, Fall 2009

\title{
For Both Love and Money: Viviana Zelizer's The Purchase of Intimacy
}

\author{
Martha M. Ertman
}

Zelizer, Viviana A. 2005. The Purchase of Intimacy. Princeton, NJ: Princeton University Press. Pp. xi + 356. \$49.95 cloth; $\$ 23.95$ paper.

Viviana Zelizer's recent book, The Purchase of Intimacy (2005), presents an innovative theory of how social and legal actors negotiate rights and obligations when money changes hands in intimate relationships - a perspective that could change how we understand many things, from valuations of homemaking labor to the 9/11 Victim Compensation Fund. This essay describes Zelizer's critique of the reductionist "Hostile Worlds" and "Nothing But" approaches to economic exchange in intimate relationships and then explains her more three-dimensional approach, "Connected Lives." While Zelizer focuses on family law, the essay goes beyond that context, extending Zelizer's approach to transfers of genetic material and concluding that her approach could point toward a more equitable resolution of disputes in and about these markets.

\section{TRANSCENDING BOTH PRICE AND PRICELESSNESS}

The best academic projects make readers think in new ways, leaving them shaking their heads, wondering how they could ever have thought the old way. Economic sociologist Viviana Zelizer's work achieves this feat. Her recent book, The Purchase of Intimacy (2005), presents an innovative theory of how social and legal actors negotiate rights and obligations when money changes hands in intimate relationships-a perspective that could change

Martha M. Ertman is Carole \& Hanan Sibel Research Professor at the University of Maryland Law School.

The author thanks Diane Hoffman, Karen Lash, Radhika Rao, and Kate Silbaugh for their comments on earlier drafts; the Washington, DC, feminist legal theory reading group for graciously sharing their responses to The Purchase of Intimacy; the University of Maryland for financial support through a summer research grant; and Sue McCarty at the University of Maryland Law School for extraordinary library research support. 
how we understand many things, from valuations of homemaking labor to the 9/11 Victim Compensation Fund. Her integrated "Connected Lives" should appeal to law and society scholars because it transcends the common tendency to treat market and nonmarket spheres simplistically, as if they were either "Hostile Worlds" (à la Michael Walzer) or "Nothing But," another monolithic system (à la Chicago-school legal economics) (1). Zelizer's recognition of economic elements in intimacy may explain why Richard Epstein (2005), reviewing The Purchase of Intimacy in the New York Times Book Review, described her "straightforward but powerful point [that the] sharp division scholars want to draw between money and intimacy does not capture the multiple relationships of ordinary people" (23). Nevertheless, he would shoo her away from law and back toward sociology, wishing she had addressed empirical questions, such as "Which couples choose to adopt prenuptial agreements, and why? Which couples keep separate property after marriage, and which do not? Does the movement of women into high-level positions in the work force alter family planning?" (23).

Many law and society scholars find Zelizer's theoretical insights about law helpful, particularly her 1994 book The Social Meaning of Money, which came on the scene just as legal economics approached ascendancy in the legal academy. ${ }^{1}$ In response to commentators like Epstein, on the one hand, and Margaret Jane Radin (1987, 1996)—who protested that legal economics reduced human experience to one dimension-on the other, Zelizer has staked out a middle ground. Her work has appealed to scholars who see both the merits of market mechanisms and the dangers of universal commodification in doctrines governing domestic relations (Silbaugh 1997; Dolgin 1997; Hasday 2005; Sanger 2007), poverty (Coven 2002), intellectual property (Rao 2000), insurance (Baker 1996, 2001; Stone 1999), tax (Staudt 1996), and property (Rose 1994), as well as commodification theory (Williams 2000; G. Cohen 2003; Case 2005). This crossover popularity is possible because of the extraordinary breadth of Zelizer's expertise, encompassing such diverse topics as life insurance, adoption, and adult intimate relationships (Zelizer 1979, 1985, 1994). I have used her analyses in my own work to argue that marketization can help alleviate power disparities both within families and among different types of families (Ertman 1998, 2003, 2007).

Zelizer's (2005) Connected Lives approach captures how people carefully define social roles, rights, and responsibilities when intimacy and monetary transactions coincide (20-22). Her argument rests on an impressive accretion of legal and social evidence showing how people and institutions negotiate economic aspects of intimacy and intimate aspects of economic life. While she relies heavily on case law-such as cohabitants' disputes

1. The Social Meaning of Money won the American Sociological Association's (ASA) Culture Section Book Award in 1996. A further measure of Zelizer's stature is that in 2003 the ASA's Economic Sociology section named its annual book prize after her. 
post-breakup, engagement ring cases, and the 9/11 Victim Compensation Fund determinations regarding recovery by surviving same-sex partners-she also marshals a wide variety of other quasi-legal and nonlegal sources, from the American Psychological Association's Code of Conduct defining impermissible intimacies to Emily Post's Etiquette advice on returning engagement rings. Of particular interest to legal scholars are her explanations of how courts fall into logical errors by engaging in Hostile Worlds or Nothing But thinking.

Perhaps because she is a sociologist rather than a law professor, Zelizer does not venture an opinion as to whether the cases she considers were rightly decided. She says from the outset that her agenda is descriptive, not normative $(5,42)$. She maps in great detail how and why people worry about intersections between intimate and monetary spheres and how law navigates these disputes. But she does not suggest policy changes, except to urge us to abandon absolute, reductionist approaches, presumably so that we might come to new and better insights. For law, this change would at a minimum facilitate a legal discourse that candidly admits overlaps between finances and intimacy. On coherence grounds alone, this shift in thinking would improve existing discussions in scholarship, as well as among lawyers, clients, and judges.

This essay proceeds in two parts. First, it details Zelizer's critique of the reductionist Hostile Worlds and Nothing But approaches. It then explains her more three-dimensional approach, Connected Lives. Her main focus is on family law, which explains why much of her crossover appeal has been in domestic relations scholarship, but her analysis could apply equally well in other contexts. Accordingly, I conclude by testing the generalizability of Zelizer's approach beyond her analysis of family relations, applying it to transfers of genetic material, a markedly more impersonal instance of contested commodification. Analytically, my extension extends Zelizer's descriptive account to a normative level. Her framework, I contend, can be applied outside family law to reinterpret the leading case on markets in genetic materials to reveal dangerous distributive consequences of the decision. It may similarly point toward a more equitable resolution of disputes in other instances of contested marketization.

\section{ZELIZER'S APPROACH: CRITIQUING THE DUALISM OF PRICE AND PRICELESSNESS}

Zelizer's main point - that money and intimacy overlap in complex ways-hardly requires a whole book. You can get it by watching a thirtysecond "priceless" MasterCard ad. One of the ads shows successive images of a father playing ball with the same child as a toddler, a young boy, and a teenager, intoning as the items and prices appear on the screen: "rubber ball: 
\$6; softball: $\$ 5$; football: $\$ 35$. Being ready for whatever parenthood throws at you: priceless. There are some things that money can't buy. For everything else there's ... MasterCard" (MasterCard n.d.).

The ad works because it taps into a paradox. It begins by treating markets and intimacy as interdependent, enumerating a few material components of parenthood to demonstrate the importance of materially providing for children. Then it veers in the opposite direction, treating market and emotional concerns as diametrically opposed by invoking the sentimentalist truism that money cannot buy love. In short, it depicts parenthood (and family generally) as simultaneously inside and outside of markets, while at the same time proclaiming an impermeable boundary between the two realms.

Zelizer's contribution is to make sense of this paradox by showing how it arises repeatedly in legal disputes, and to reframe it to help us better understand situations where money seems out of place, yet it keeps showing up nonetheless. Her critique of the dueling approaches to contested commodification addresses each half of this paradox in turn, looking first at pricelessness, then at price. Ultimately, she aims to resolve it by embracing both.

For all the straightforwardness of its core message, the book is also complex. Zelizer makes her main point in concrete language, emphasizing it so strongly that she repeats herself perhaps more than is necessary. But close examination shows more going on. Consistent with her determination to reveal plural meanings of monetary exchanges, the very title of The Purchase of Intimacy carries multiple meanings. Zelizer (2005) means to address both "purchase" in the obvious sense of paying with money and in the more subtle sense of "purchase" as grasp, "how the powerful grip of intimacy affects the ways we organize economic life" (2). The book achieves these goals, offering us new ways to understand both how money affects intimacy and how intimacy affects economic life.

\section{Pricelessness: Hostile Worlds}

First, pricelessness. Zelizer's term for the "pricelessness" approach, Hostile Worlds, vividly evokes resistance, even aversion, in contrast to the neutrality of "separate spheres" (20). Having set the tone, she systematically reveals Hostile Worlds' two-dimensionality. Hostile Worlds views, which sometimes take the guise of communitarianism, maintain sharp, impermeable boundaries between money and contested commodities like love, babies, and body parts. A Hostile Worlds lens zooms in on one sentence of the MasterCard ad: "There are some things money can't buy." In In re Baby M (1988), arguably the most widely discussed case of contested commodification, the New Jersey Supreme Court used almost the exact phrasing in refusing to enforce a surrogacy contract between Mary Beth Whitehead and William 
Stern: "There are, in a civilized society, some things that money cannot buy" (1249).

Hostile Worlds positions often rely on similar assertions, like Michael Walzer's claim that "blocked exchanges," such as money for sex, reflect our "shared morality and sensibility" (quoting Walzer in Zelizer 2005, 22). Talcott Parsons, Zelizer notes, also "sharply differentiated between the market and the family" (Zelizer 2005, 43). Zelizer systematically debunks Hostile Worlds assumptions by listing a wide range of intimate sexual relationships, each involving different rules regarding economic exchange within the relationship, only some of which are socially or legally sanctioned (56). Dating often involves one person picking up the tab, as opposed to "hooking up," in which intimates each pay their own way (114-15). Prostitution involves paying for sex (124-29), while engagement involves the exchange of a valuable ring for the promise to marry, leading to a wedding and, often enough, an expensive party thrown by the bride's family (108-14). ${ }^{2}$ Marriage, meanwhile, generally involves property and income sharing. ${ }^{3}$ Zelizer builds on this factual foundation by enumerating legal doctrines that distinguish among these various intimate relationships, recognizing that matching a particular relationship to a doctrine can result in-or preclude-financial recovery. For example, she explains, the law of consortium generally entitles a spouse, and only a spouse, to recover money for the loss of companionship, affection, and sexual relations. Palimony, in contrast, entitles nonmarital couples to enforce contractual promises, unless the agreement was meretricious or mainly related to sex. As Zelizer sees it, the rule barring enforcement of meretricious cohabitation agreements is "a Hostile Worlds concept par excellence" (59):

Lawyers working in the American legal system spend a great deal of time avoiding any arrangement that can be construed as legally binding compensation for sexual services. They therefore make distinctions that separate direct reward for sexual services from legitimate contracts. . . . Most famously, the controversial 1976 Marvin $v$. Marvin decision stated that "express agreements will be enforced unless they rest on an unlawful meretricious consideration." (59)

According to Zelizer, courts follow predictable analytical steps to resolve cases like Michelle Marvin's claim against actor Lee Marvin to enforce his promises to support her.

2. Zelizer notes a recent study documenting a $\$ 9$ billion industry in engagement rings and wedding bands (108). Surprisingly, and apropos of Zelizer's main point, this report claimed that Americans spend about as much for rings as for sexual services (119, citing Conde Nast Bridal Infobank American Wedding Study 2002).

3. Zelizer lists heterosexual intimate relationships, differentiated in part by different economic exchanges (56-61). 
First, courts consult a list of what Zelizer dubs "recognized relations" (60), such as spouses, cohabitants, or master and servant. Next, they consult precedent and analogy, sometimes making new law by extending precedent to new contexts or claiming precedents contradict each other. Finally, they bind the relationship as categorized with the precedent as interpreted to justify a distributive outcome (60-61). She explains that this process often produces a Hostile Worlds justification. For example, the California Supreme Court allowed Michelle Marvin to assert contract claims against Lee Marvin because their agreement was emotionally and socially intimate rather than primarily sexual. In Hostile Worlds terms, enforcing that cohabitation contract would not cause sexual intimacy and monetary transaction to corrupt one another. Most illuminating, the doctrine reveals the internal inconsistency of Hostile Worlds reasoning. Under the holding of Marvin v. Marvin (1976), courts can only enforce monetary promises in intimate relations if the intimate and financial worlds remain separate. Yet by awarding damages to compensate for failure to keep an intimate promise, the recovery itself breaches the boundary between the purportedly separate spheres.

Zelizer is hardly the first to recognize the limits of Hostile Worlds reasoning. A wide range of scholars, from feminist sociologist Kathleen Barry (1995) to Chicago School economist Gary Becker (1991), have argued for radical commensurability by showing that pricelessness-radical incommensurability-collapses under its own weight. ${ }^{4}$

\section{Price: Nothing But Approaches}

Returning to the phrasing of the MasterCard ad, we next address complete commensurability, which can be described as a price-based view of the world. The other side of the Hostile Worlds coin, Nothing But appears less frequently than the purported pricelessness of Hostile Worlds. Nevertheless, it holds sway, especially in academic circles. Nothing But views take advantage of Hostile Worlds' failure to account for the obvious overlap of intimacy and money in parenthood as well as in the legal doctrines Zelizer discusses. Where Hostile Worlds reasoning presupposes a two-dimensional worldmarket on one side and family on the other-Nothing But views reduce social and legal life to one dimension. Nothing But approaches, according to Zelizer (2005), contend that a "simpler principle . . actually explains what is going on" (29). She catalogs these advocates into three camps: Nothing But economic rationality, Nothing But culture, and Nothing But politics. Legal academics will readily recognize the first group as Chicago school legal economists, contending along with Gary Becker (1991) and Richard Posner (1992)

4. A postmodern focus on power as an organizing principle similarly would reject Hostile Worlds approaches to issues like prostitution. See Foucault (1978). 
that parenthood, marriage, friendship, sex, and other transactions that most people think of as outside the market can nonetheless be viewed as Nothing But rational economic transactions. ${ }^{5}$ This type of Nothing But scholarship, for example, justifies postdivorce income sharing on the ground that marriage is a type of long-term contract in which homemaking spouses expect a return on "relationship-specific investments" (Zelizer 2005, 30). ${ }^{6}$

Cultural reductionists, in contrast, see human relations as Nothing But "beliefs or ideological scripts" (29), while political reductionists such as Kathleen Barry (1995) view prostitution as Nothing But coercion (78). In describing the Nothing But category, Zelizer groups together views that seldom meet, let alone marry. Placing Gary Becker's fundamental premise of universal markets alongside Kathleen Barry's work positing universal coercion in sex work provides a novel intellectual organization. Moreover, and more importantly, the grouping reveals the limits of both frameworks. Taking prostitution as an example, Nothing But markets would justify legalizing prostitution contacts, while Nothing But coercion would prohibit such arrangements. If legal theory purports to both explain and predict outcomes, Nothing But fails because it could justify opposite outcomes, depending on one's ideological and disciplinary commitments.

Zelizer illustrates Nothing But approaches by exploring social and legal aspects of household governance. Defining "household" as "two or more people who share living quarters and daily subsistence over substantial periods of time" (Zelizer 2005, 213), she shows overlap of intimacy and monetary transfers because households, so defined, include paid caregivers, foster children, lovers, relatives, and family businesses in which household members work. Household members, she explains, consequently develop rights and obligations involving the intersection of intimacy and economic activity. A Hostile Worlds formulation of legal doctrine regarding postdivorce income sharing could deny recovery based on homemaking service on the grounds that paying for work done for those we love corrupts that love. The leading alternative, a Nothing But framework, might see this household as Nothing But a firm like any other, or as a power structure. Viewing it as a firm would justify compensation. Viewing it as a power structure could yield the same result, though perhaps for tort-based restitution rather than contractual exchange-based entitlements.

Zelizer only briefly considers a third major strand of commodification discourse: moral arguments. Having made that choice, it makes sense that she does not mention Michael Sandel, the leading moral philosopher contesting

5. The description is itself reductionist. For example, Richard Posner's (1992) muchdiscussed book Sex and Reason combines economic analysis of sexuality with sociobiological claims about genes' utility maximization.

6. Zelizer (2005) notes David Friedman's contention that spouses make "relationshipspecific investments," resulting in a "bilateral monopoly with associated bargaining costs" (quoting Friedman, 172, 30-31). See also L. Cohen (1987). 
universal marketization. If she had, she might have categorized his view as Hostile Worlds extraordinaire, since he forcefully argues against markets in contested commodities like kidneys and genetic improvements on the grounds of both coercion and corruption (Sandel 1998, 2007). Zelizer does, however, address some of Sandel's concerns, contending that moral objections fail to account for the vast complexity where market and intimate realms meet.

Although participants, observers, and third parties commonly mark such distinctions with moral discourse and moral practice, rarely are the defining interactions on one side of a boundary or the other universally acceptable or unacceptable in themselves; they depend on context. Sexual intercourse, for example, becomes an enforceable obligation for spouses, an option for lovers, and a forbidden transgression for lawyerclient pairs. Similarly, expensive gifts become obligations in some relations, options in others, and forbidden transgressions in still others. The matching of relation, transaction, and medium matters crucially. (Zelizer 2005, 99)

In short, moral reasoning, like Hostile Worlds analyses, simply lacks the capacity to measure the many complex things that people carefully, and continuously, negotiate on the boundaries of intimacy and markets.

Similarly, the reductionism of Nothing But approaches fails to reflect the extraordinary complexity of how we live our financial and intimate relationships. We fold a $\$ 10$ bill into a stork to transform plain currency into a gift, and hand our dinner hosts a bottle of wine at the door rather than a $\$ 20$ bill. Even Landes and Posner (1978), arguing for a market in babies, stopped short of advocating markets in older children and specific performance in baby markets. Along the same lines, Nothing But coercion approaches use analytically problematic tools like false consciousness to explain the claims like those by some erotic dancers that sex work is akin to other types of work, and sex workers should be able to enjoy rights and protections of other workers (Query, Montoya, and Funari 2000).

\section{Zelizer's Alternative: Connected Lives Approaches}

This ubiquitous complexity suggests that Zelizer could well have called her approach "Complex Lives." Indeed, she dubbed it "Differentiated Ties" in

7. Sandel $(1998,2007)$ takes a moral stance to critique these transactions either as coerced (no one would agree to sell a kidney unless forced by economic circumstances) or as corrupt (as when genetic engineering corrupts the giftedness of human life). 
earlier iterations (Zelizer 2000; Williams and Zelizer 2005). Ultimately, she chose to call it Connected Lives. Zelizer (2005) observes that

in everyday life, people invest intense effort and constant worry in finding the right match between economic relations and intimate ties: shared responsibility for housework, spending of household income, care for children and old people, gifts that send the right message, provision of adequate housing for loved ones, and much more. (3)

As conditions change, people renegotiate those ties (and their markers). Cases she marshals to prove her point are wide-ranging factually and doctrinally, encompassing the Louisiana supermarket entrepreneur John Schwegman's refusal to share his business holdings with his long-term cohabitant Mary Ann Blackledge (47-48); Wichita attorney Jerry Berg's sexual behavior with his divorce clients (94-95); the contested will of Johnson \& Johnson heir J. Seward Johnson, who bequeathed his $\$ 2.4$ billion fortune to his much younger housekeeper after marrying her (158); and Hildegard Borelli's unsuccessful attempt to enforce a contract to a share of her husband's property in exchange for caring for him in his final illness (287-88).

Borelli v. Brusseau (1993), familiar to many family law and contracts teachers, nicely illustrates the limited facility of both Hostile Worlds and Nothing But approaches. The California appellate court refused to enforce Mr. Borelli's promise to share his property with his wife in exchange for her personally caring for him during his final illness, reasoning that as his wife she was obliged to provide that care, conveniently ignoring that Mr. Borelli used a premarital contract to avoid his companion duty to provide for her. According to Zelizer, Borelli illustrates deficiencies in Hostile Worlds and Nothing But approaches:

Both sides of the Borelli v. Brusseau court decision impale themselves on the horns of Hostile Worlds/Nothing-But reasoning. One horn declares that marriage must remain sacred, insulated from commercial transactions; the other horn announces that marriage is a commercial transaction. Both sides thus fail to recognize one of this book's most important revelations: that every relationship of coupling, caring, and household membership repeatedly mingles economic transactions and intimacy, usually without contamination, yet relations of coupling, caring, and household membership operate differently from other relationships. (Zelizer 2005, 288)

The question Zelizer would have us ask, rather than whether intimates should engage in economic exchanges (a pointless question since they do it all the time), is "what sorts of economic transactions match which intimate relations" (288). 
By recognizing fuzzy boundaries between intimate and commercial realms, Zelizer reveals the false dichotomies that underlie both communitarian and legal economic discourse. ${ }^{8}$ In other words, labeling a contest as a competition between freedom of contract, on one side, and dignity, equality, and solidarity, on the other, underappreciates the complex ways that finances and intimacy intersect. She is in good company here, and acknowledges as much by applauding the work of legal scholars such as Carol Rose (1992, 1994), Reva Siegel (1994), Margaret Jane Radin (1996), Cass Sunstein (1997), Linda Hirschman and Jane Larson (1998), Martha Nussbaum (1998), and Joan Williams (2000), who also tread waters between the extremes of commensurability and incommensurability (78-92).

Zelizer defends the Connected Lives approach by showing that even when we claim to rope off an aspect of social life, or a particular thing as beyond the market's crass calculations, we still tolerate and even encourage overlap between the two supposedly separate spheres (Zelizer 2000). She argues for a more muted response to these overlaps, coupled with a wider recognition of how frequently they occur. Money, in this view, is only one element of intimate relationships, and its presence or absence should not determine legal support or punishment for particular relations. Like a map of the world that depicts North America as properly proportioned in relation to other continents - unlike common maps produced in the United States that exaggerate our own country's prominence-Zelizer's work invites us to redraw the boundaries between the market and the family, and, in doing so, related boundaries between secular and sacred, instrumental and altruistic, and public and private.

Zelizer's Connected Lives matrix documents the complex relationship between monetary exchanges and intimate relationships by enumerating four steps in the analysis of relational work by courts. Using her model, the remainder of this essay summarizes Zelizer's argument that courts engage in four stages of "relational work" (Zelizer 2005, 37) when regulating overlaps between intimacy and monetary exchange: (1) relations-naming a relationship, erecting a boundary by naming it, and marking it with distinctive practices; (2) transactions - examining a particular transaction; (3) media-evaluating the media of exchange, such as with an accounting system or other tokens; and (4) boundaries - establishing or affirming boundaries around distinctive combinations of relations, transactions, and media. This fourth step holds particular relevance for legal purposes. If discourse produces approval for the economic transaction within the boundary that has been created, courts may grant recovery; if not, parties seeking relief may well be out of luck.

8. For a discussion of the false dichotomies common in commodification discussions that diametrically oppose markets with altruism, resulting in two lines of discourse that travel along fixed rails with no hope of genuinely engaging one another, see Ertman and Williams (2005, $1-5)$. 
There is a poststructuralist cast to Zelizer's approach. For poststructuralist feminists, sex is a discursive construct rather than a biological fact. In this view, sex becomes an effect of discourse, not a cause of it. This perspective fatally undermines policies based on contentions that men and women are essentially different (see Fuss 1989; Butler 1990). Zelizer's Connected Lives approach resembles this position by rejecting essentialist notions of money and intimacy (Ertman 2003), and revealing that Hostile Worlds is not a truth that causes outcomes in cases. Instead, Hostile Worlds is an effect of the larger process of creating and maintaining a complex interaction between economic and purportedly noneconomic relationships. In Zelizer's (2005) words, "Hostile Worlds ideas and practices emerge from the effort to mark and defend boundaries between categories of relations that contain some common elements, could be confused, and would threaten existing relations of trust if confused" (36).

Anthropologists have long recognized the tendency of items and relationships to evade essentialist categorization by slipping in and out of the market. Law and social customs differentiate types of transactions and then use the binary of "property" and "person" to justify outcomes (Appadurai 1986, 3). In the most notorious instance of overcommodification, US law protected a market in human beings and then abolished it. More prosaically, things routinely go in and out of market status. Cocaine was freely sold like other commodities in the nineteenth century (Musto 1973, 7), evidenced by its place in the Sears Roebuck catalog (Buxton 2006, 16-17), before states and Congress limited who could sell and distribute it in the early twentieth century (Musto 1973, 54). Similarly, a Coca-Cola bottle from 1902 (originally containing cocaine, giving the drink both its name and its kick) (3) went from being trash to a collector's item sold on eBay over the course of the twentieth century (Rodrigues 2005).

Zelizer's framework similarly traces legal doctrines such as coverture, consortium, and rules allocating rights and obligations in courtship, engagement, cohabitation, and marriage. Along the way we are treated to facts that invite us to see these doctrines in new light. I, for one, did not know that meddling parents, rather than romantic rivals, may have been the most common defendants in alienation of affection suits in the early twentieth century (Zelizer 2005, 70). Nor that engagement rings only became common in the nineteenth century, starting with men and women mutually exchanging rings (110). Nor that in 1996 families in the Dominican Republic received a whopping $\$ 1.14$ billion in the form of remittances from relatives working elsewhere (222).

Zelizer crafts her theory out of this kind of factual material. Her analysis of loss of consortium is illustrative. She first describes nineteenth-century doctrine limiting who could assert loss of consortium claims (husbands, not wives) and what they could complain about (the wife's lost services, but not companionship, much as a master would recover for the loss of a servant's 
services) (71-72). Not until the 1950s and 1960s, Zelizer explains, did courts generally equalize husbands' and wives' loss of consortium standing and routinely compensate for lost companionship (72-73). This change, according to Zelizer, required courts to do what she calls the "relational work" (75) of naming intimate relationships, designating specific practices, establishing rights and obligations that come with the category, and allocating any losses recognized by the law (62). Zelizer deploys her framework to make sense of the evolution of loss of consortium doctrine.

First, they were deploying-and in the long term significantly modifying - the grid of relationships available for legal action and the distinctions among them. We see them, for example, increasingly distinguishing husband-wife relationships from those of master-servant and parent-child. Second, they were matching relations, transactions, and media, likewise altering legally acceptable definitions as they went along. Third, courts partially reversed their reasoning. In addition to deducing appropriate transactions and media from the publicly recognized relationship, they also reasoned from observed transactions to the relationship's quality. In cases of injury to a spouse we see the participants debating the character of interactions between spouses-how loving, how attentive, and so on-in assessing appropriate damages. (75)

This pattern continues. Some courts have extended loss of consortium to cohabitants and same-sex partners as well as parent-child relationships (75, note 4), as when a Californian recovered loss of consortium damages arising out of her female partner's fatal mauling by their neighbor's pitbull (Smith $v$. Knoller, 2002).9

The expanded consortium doctrine and related news coverage reflect two distinct levels of controversy: the kind of contests over expanding legally recognized intimate relationships that have produced Defense of Marriage Acts in most states, and doubts about the increased monetization of intimate matters in life and in law. Zelizer notes crossover economist Robert Kuttner's assertion that "as the market vogue has gained force, realms that used to be tempered by extra-market norms and institutions are being marketized with accelerating force" (Kuttner quoted in Zelizer 2005, 25). Zelizer's approach takes us beyond nostalgia for a less marketized culture, challenging us to rethink the easy assumption that increased marketization is always a bad thing. Her economic sociological stance looks more closely at why we worry about marketization in some circumstances but not in others. It improves on existing ways of seeing the boundaries between markets and the rest of human interactions by recognizing subtle and important gradations of

9. The Smith v. Knoller (2001) press coverage shows how deeply people care about how we navigate the boundaries of intimacy and money and, moreover, how law plays a unique role in expressing and justifying those ever-changing boundaries. 
commensurability and offering principled answers to questions like why we worry more about prostitution than engagement rings or more about human beings selling their kidneys than about intermediaries like organ banks making money on the deal.

Imagine a man picking up the bill for a woman's lunch at an expensive restaurant. He might be a lobbyist taking a senator out to urge passage of a bill, an attorney hoping to win a client's business, a man treating his date, a boss taking his secretary out to lunch, or some combination of the above. In some of these contexts, the fact of paying could result in legal punishment. The senator might face sanctions for being improperly influenced; and if the lawyer paying for his client's lunch is also making romantic advances, he might violate ethical rules. Moreover, the fact of paying does not cleanly map onto social power dynamics. The one who pays holds more power when the boss pays for his secretary, but an attorney taking a potential client to lunch hopes that she will become his boss by retaining him. Thus, in line with Zelizer's basic premise, the mere exchange of money in work relationships does not distinguish between permissible and impermissible interactions, and being the payor or payee does not tell us much either. Money is similarly complex between intimates. If these two lunchmates are acquaintances going out for the first time, paying for lunch may signal that it is a date. If they met through an escort service, the relationship could be meretricious. If, instead, the two met at their place of worship, paying for lunch may signal the man's intention to play his part of the traditional heterosexual exchange of food and shelter in exchange for sex and homemaking. As is the case for work relationships, the exchange of money may or may not be associated with legal sanctions. In short, there are many ways to understand the co-constitutive role of money and social roles, and law needs a theory to coherently regulate these interactions.

At a minimum, Connected Lives - in particular its focus on definition and boundary-drawing - provides a good start. It certainly sheds light on dating, romance, and care work. If Connected Lives also helps judges and policy makers understand and resolve other issues, it may well provide a theoretical basis for a legal regime that recognizes incomplete commensurability. The remainder of this essay explores this possibility by briefly applying Zelizer's analytic tools to contract and property disputes about genetic materials.

\section{APPLYING ZELIZER'S FRAMEWORK TO THE MARKET FOR GENETIC MATERIAL}

If Zelizer's Connected Lives model works outside family relationships, The Purchase of Intimacy could influence the way judges decide cases involving disputes in far-flung areas such as biotechnology and intellectual property. 
Consider the leading case addressing markets for genetic material, ${ }^{10}$ Moore v. Regents of the University of California (1990). John Moore's claims against the University of California, his doctor, and biotech companies arose out of his treatment for hairy cell leukemia. His doctor, David Golde, used Moore's blood, sperm, and other bodily materials to create and then patent a cell line, which Golde, the university, and biotechnology companies marketed, all without Moore's consent. The California Supreme Court declined to recognize Moore's conversion claim, but it did recognize another dimension of his injury by allowing him to sue Golde for breach of fiduciary duty. In short, the court recognized rights based in breach of trust rather than property or contract, ultimately reserving property rights in Moore's tissues for others.

In a situation where scholars have not reached consensus about the case (Rao 2000, 373; Kahn 2000; Boyle 2002; Goodwin 2006, 327), Zelizer's lens clarifies matters considerably. In Moore, the court adopted a Hostile Worlds view by describing Moore's claims to privacy and dignity as "round pegs" that should not be forced into the "square hole of property" (Moore, 491). This rubric treated the market-oriented nature of property as fundamentally different from nonmarket concerns of privacy and dignity. Justice Arabian's concurrence even more clearly used Hostile Worlds language to condemn Moore's conversion claim for "commingl[ing] the sacred with the profane," contending that Moore, in seeking to protect "a right to sell one's own body tissue for profit," asked the court "to regard the human vessel- the single most venerated and protected subject in any civilized society — as an equal with the basest commercial commodity" (Moore 497, Arabian, concurring, italics in original). Yet the very same court allowed artificial persons, such as the university and biotechnology companies, to treat Moore's genetic material as a commodity:

[T] he theory of liability that Moore urges us to endorse threatens to destroy the economic incentive to conduct important medical research. ... Because liability for conversion is predicated on a continuing ownership interest, "companies are unlikely to invest heavily in developing, manufacturing, or marketing a product when uncertainty about clear title exists" (quoting Congress, ${ }^{11}$ Moore 495-96, majority opinion).

In short, in a contest over commodifying genetic material, the court rejected Moore's property claims in order to support property claims asserted by the university, biotechnology companies, and Dr. Golde.

In contrast, Justice Mosk's dissenting opinion in Moore represented a view that moves between the Nothing But and Connected Lives perspectives.

10. By genetic "material," I mean both parts of human bodies (like blood and tissue) and genetic information (like family histories of genetic disease).

11. Office of Technology Assessment, New Developments in Biotechnology: Ownership of Human Tissues and Cells. 
He began in Nothing But terms, broadly defining property as "'every species of right and interest capable of being enjoyed . . . upon which it is practicable to place a money value'" (Moore, 509, Mosk, dissenting, quoting Yuba River Power Co. v. Nevada Irrigation District 1929, 129). Still proceeding on the assumption of expansive market thinking, he then asserted that Moore "at least had the right to do with his own tissue whatever the defendants did with it: i.e., he could have contracted with researchers and pharmaceutical companies to develop and exploit the vast commercial potential of his tissue and its products" (Moore, 510). But later in his dissent Justice Mosk moved beyond Nothing But thinking to simultaneously embrace property and personhood by concluding that "every individual has a legally protectable property interest in his own body and its products," an interest grounded in "a profound ethical imperative to respect the human body as the physical and temporal expression of the unique human persona" (515).

The contrast between Justice Mosk's linking of dignity and markets and Justice Arabian's diametrical opposition to linking them reveals the superiority of Connected Lives approaches over Hostile Worlds or Nothing But views. Justice Mosk grounds Moore's property interests in the dignitary interest of "the unique human persona," as well as in the dangers of granting the university's, Dr. Golde's, and the biotechnology companies' greater interests in Moore's tissues than Moore himself enjoyed. By invoking property and personhood in the same breath, his dissent embraces the "both/ and" spirit central to Zelizer's Connected Lives approach. The dissent transcends the two-dimensionality of Hostile Worlds and the one-dimensionality of Nothing But approaches, offering precisely the kind of three-dimensional perspective that might capture gradations in commensurability.

This simultaneous embrace of purported opposites invites an extension of Zelizer's theory to a normative level, using Justice Mosk's insights about the distributive injustice of the majority's allocation of all property rights to the university, physician, and companies. While he does not explicitly condemn the majority for granting artificial persons greater rights to human tissue than the natural persons from whom the tissues were taken, the basic unfairness of treating the two types of parties differently is central to his opinion.

In the remainder of this essay, I will apply Zelizer's (2005) four-part Connected Lives analysis to show how it allows us to "stop agonizing over whether or not money corrupts, but instead analyze what combinations of economic activity and intimate relations produce happier, more just, and more productive lives" (298).

\section{Classifying the Relationship}

The majority opinion in Moore looks to two kinds of relationshipsmedical treatment and research-in order to separately analyze Moore's 
fiduciary duty claims against Golde, and his conversion claims against the university, biotechnology companies, and Golde. Each type of relationship contains particular rules for conduct that apply to one party in the transaction, such as the physician's and researchers' obligations to obtain informed consent. By concluding that Moore could sue Dr. Golde for breach of fiduciary duty arising out of his medical treatment but not sue the university and other defendants for conversion arising out of the research, the court drew a new boundary to differentiate between rights and obligations arising in medical treatment and research. According to the majority opinion, this boundary is policed by the "well-established principle" (483) that treating physicians owe their patients a fiduciary duty to disclose all material information in obtaining consent to treatment, including economic and research interests that might affect the doctor's medical judgment (485). By separating the tangled relationship between Moore and Golde into treatment and research, the court set the stage for evaluating legal rights and obligations arising out of each separate relationship.

\section{Examining Transactions within the Relationship}

Separating Moore's interactions as the patient and Golde's as the treating physician from their interactions as research subject and researcher highlights the different boundaries within each relationship. Both physicians and researchers must obtain informed consent from patients and subjects, but physicians owe additional fiduciary duties that researchers do not. The court's focus on Golde's fiduciary duty to Moore as a physician precluded imposing similar duties on the university and biotechnology companies, since they were not physicians and thus not required to obtain Moore's informed consent for medical procedures (486-87). Taking these defendants and their likely deep pockets out of the equation has distributive consequences, limiting patient/research subjects' prospects of recovery.

One transaction in the seven-year relationship between Moore and Golde stands out as a problematic blurring of treatment, research, and commercial relationships. Years after Moore's surgery, he moved to Seattle, and flew to Los Angeles periodically for Dr. Golde to withdraw blood, bone marrow, and semen. Moore asked Dr. Golde if a Seattle doctor could do this work to save him the trip, to which Dr. Golde responded by offering to pay for the plane tickets and to house him at the upscale Beverly Wilshire Hotel. Later, Moore refused to sign a form granting the University of California all rights to cell lines developed from his blood or bone marrow (Skloot 2006, 41). This transaction and the many related transactions of Moore traveling to California for what he thought was medical treatment, when Golde was also mining his genetic material for research and commercial gain, form the centerpiece of the court's analysis. 


\section{Evaluating the Media in Which Economic Exchanges Occurred}

Media, in Zelizer's analysis, reflect and constitute social relationships. For example, a boss might give a retiring employee a gold watch, and a man intending to become engaged to a woman may give her a diamond ring. The exchanges themselves are highly stylized, such as presentation of the watch with fanfare at a retirement party or presentation of the ring nestled in dessert as the culmination of a romantic dinner to be placed on the fourth finger of the woman's left hand (Zelizer 2005, 37-38). According to Zelizer, we often reverse the significance of media, mistakenly thinking that media and transactions transform relations. Instead, just as the watch does not create retirement or the ring create an engagement, the tokens reflect the social choice already made.

In the Moore case, exchanges of value are supposed to take different forms and go in different directions in medical treatment and research. Money is the most obvious medium of exchange, though barter and perks like plane tickets and a night in a hotel suffice. Patients pay their doctors substantial sums of money. In contrast, researchers often pay their subjects, but far more modest sums, often as a token recognition of inconvenience and perhaps to signal separation of subjects' claims from their genetic or other material by virtue of their having accepted payment for their transfer.

In Moore, we might say that the court recognized Moore's fiduciary duty claim in part because Golde provided improper media by offering to pay for plane tickets and to house Moore in swank digs, and also that the exchange of money or its equivalent was flowing in the wrong direction, from physician to patient instead of the other way around. It also held that when the medium of exchange was valuable genetic material, transferred from Moore to the defendants under false pretenses, the false pretenses mattered more than the fact of the exchange. By focusing on the general social benefit of medical research, the court effectively implied an exchange of Moore's genetic material for general social benefits of research. Had the court more closely examined media, as Zelizer suggests, it might have recognized the distributional asymmetry of allocating all monetary benefits flowing from the exchange of genetic material to the researchers. ${ }^{12}$

\section{Drawing Boundaries between Proper and Improper Economic Exchanges within Relationships}

In everyday life, people use names and practices to mark boundaries between medical and research relations and between participants in those

12. For a similar argument, see Rao (2007). 
relations. Patients and office personnel call treating physicians "doctor," and professional rules require that doctors and patients refrain from sexual intimacy during the course of treatment. Institutions governing research, for their part, mark boundaries between themselves and research subjects with names like "principal investigator" and "research participant" and practices like requiring Institutional Review Board (IRB) approval for human subject research. Elaborate IRB requirements are meant to protect research participants from harm. In addition, IRB practices mandate informed consent through consent forms and notice to subjects that they may withdraw from participation in the study. For purposes of Zelizer's format, it is worth noting that IRB procedures also require detailed disclosure of any payments made to research subjects.

Consistent with Zelizer's framework, the Moore court delineated improper practices within the doctor/patient and researcher/subject relationships. However, while it recognized Moore's breach of fiduciary duty claim for Dr. Golde's failure to disclose parallel research and medical treatment, it did not condemn Golde and his fellow researchers for failing to obtain Moore's informed consent to turn his genetic material into an extraordinarily lucrative commodity.

A case decided thirteen years after Moore suggests how doctrine might evolve to more precisely account for shades of commensurability in relationships between genetic researchers and the subjects who provide raw material for that research, thus reflecting the Connected Lives approach. In Greenberg v. Miami Children's Hospital (2003), a federal trial court in Florida, like the California Supreme Court in Moore, gave priority to the property claims of hospitals and universities over the human beings who provided genetic material for research and medical treatment. However, the court in Greenberg also recognized a particular type of researcher-subject relationship that was akin to a partnership. This designation, coupled with analysis of transactions and media, allowed the court to recognize research subjects' claims for restitution.

In Greenberg, families with Canavan disease provided biological samples and extensive family information to researchers to hasten isolation of the gene associated with the disease and to improve treatment. When the university patented the gene and moved to limit access, the research subjects sought accessibility to the products of that information (i.e., free or low-cost genetic testing) rather than a piece of the profits on conversion grounds. The court refused. But, more importantly for our purposes, the court recognized the plaintiffs' right to assert a claim for unjust enrichment. This restitution claim - a cross between contract and tort-could prevent universities and other artificial persons from retaining benefits wrongly obtained from those research participants.

In the spirit of Zelizer's Connected Lives approach, the court classified the relationship as "more than just a donor-donee relationship" (Greenberg 2003, 1072) and laid the foundation for recognizing the participants' 
entitlement to a measure of control over the fruits of their implicit partnership: "[T]he facts paint a picture of a continuing research collaboration that involved Plaintiffs also investing time and significant resources in the race to isolate the Canavan gene. Therefore, given the facts as alleged, the Court finds that Plaintiffs have sufficiently pled the requisite elements of an unjust enrichment claim" (1073). By treating the transaction as a gift for purposes of conversion doctrine and an exchange for purposes of unjust enrichment claims, the court recognized the complexity that Zelizer makes central to her argument. This precision invites new methods to chart the complex ways that money, control, and scientific research interact. Moreover, by recognizing the research participants' unjust enrichment claim, a hybrid of tort and contract, the court invoked the type of doctrinal hybridity that Zelizer's Connected Lives contemplates. Indeed, the complexity of the overlap of money and genetic material demands this kind of case outcome.

\section{CONCLUSION}

The Purchase of Intimacy identifies, describes, and critiques reductionist approaches to regulating overlaps of intimacy-Hostile Worlds, which falsely assumes an impermeable barrier between markets and intimate relationships, and Nothing But, which subsumes these complex transactions within something bigger, such as market exchange. By identifying Connected Lives, a nuanced alternative approach that avoids the absolutes of reductionist approaches, Zelizer offers a perspective that focuses attention on incomplete commensurability, an essential task where market and supposedly nonmarket realms intersect. In doing so, Zelizer's approach gives judges, academics, lawyers, and lay people a vantage point on markets and intimacy that reflects how people actually live their lives. The utility of Connected Lives is further demonstrated by applying it beyond Zelizer's context of intimate relationships, to critique the outcome of Moore v. Regents of the University of California (1990) and to suggest the benefits of a more nuanced approach to marketizing genetic materials in research.

\section{REFERENCES}

Appadurai, Arjun. 1986. The Social Life of Things: Commodities in Cultural Perspective. New York: Cambridge University Press.

Baker, Tom. 1996. On the Genealogy of Moral Hazard. Texas Law Review 75 (2): 237-92.

- 2001. Blood Money, New Money, and the Moral Economy of Tort in Action. Law ES Society Review 35 (2): 275-320.

Barry, Kathleen. 1995. The Prostitution of Sexuality. New York: New York University Press. Becker, Gary S. 1991. A Treatise on the Family. Cambridge, MA: Harvard University Press. 
Boyle, Joyce. 2002. Note. To Pay or Not to Pay, That Is the Question: Finding an Intermediary Solution Along the Moore Spectrum. Journal of Medicine $\mathcal{E}$ Law 7 (1): $55-78$.

Butler, Judith. 1990. Gender Trouble: Feminism and the Subversion of Identity. New York: Rutledge.

Buxton, Julia. 2006. The Political Economy of Narcotics: Production, Consumption and Global Markets. New York: Zed Books.

Case, Mary Ann. 2005. Pets or Meat. Chicago-Kent Law Review 80 (3): 1129-50.

Cohen, Glenn. 2003. Note. The Price of Everything, The Value of Nothing: Reframing the Commodification Debate. Harvard Law Review 117 (2): 689-710.

Cohen, Lloyd. 1987. Marriage, Divorce, and Quasi Rents: "I Gave Him the Best Years of My Life." Journal of Legal Studies 16 (2): 267-303.

Coven, Martha B. 2002. The Freedom to Spend: The Case for Cash-Based Public Assistance. Minnesota Law Review 86 (4): 847-911.

Dolgin, Janet L. 1997. The Fate of Childhood: Legal Models of Children and the ParentChild Relationship. Albany Law Review 61 (2): 345-431.

Epstein, Richard A. 2005. For Love or Money. New York Times, September 18, section 7, 23.

Ertman, Martha M. 1998. Commercializing Marriage: A Proposal for Valuing Women's Work through Premarital Security Agreements. Texas Law Review 77 (1): 17-112.

- 2003. What's Wrong with a Parenthood Market? A New and Improved Theory of Commodification. North Carolina Law Review 82 (1): 1-59.

- 2007. Mapping the New Frontiers of Private Ordering: Afterword. Arizona Law Review 49 (3): 695-715.

Ertman, Martha M., and Joan C. Williams, eds. 2005. Introduction. In Rethinking Commodification: Cases and Readings in Law and Culture. New York: New York University Press.

Foucault, Michel. 1978. A History of Sexuality. Vol. 1. Trans. Robert Hurley. New York: Pantheon Books.

Fuss, Diana. 1989. Essentially Speaking: Feminism, Nature, and Difference. New York: Routledge.

Goodwin, Michele. 2006. Formalism and the Legal Status of Body Parts. University of Chicago Legal Forum 2006 (1): 316-88.

Hasday, Jill Elaine. 2005. Intimacy and Economic Exchange. Harvard Law Review 119 (2): 491-530.

Hirschman, Linda R., and Jane E. Larson. 1998. Hard Bargains: The Politics of Sex. New York: Oxford University Press.

Kahn, Jonathan. 2000. Biotechnology and the Legal Constitution of the Self: Managing Identity in Science, the Market, and Society. Hastings Law Journal 51 (5): 909-52.

Landes, Elisabeth M., and Richard A. Posner. 1978. The Economics of the Baby Shortage. Journal of Legal Studies 7 (2): 323-48.

MasterCard. n.d. Priceless: "Catch." http://www.priceless.com/us/personal/en/pricelesstv/ index.html (accessed October 24, 2008).

Musto, David F. 1973. The American Disease: Origins of Narcotic Control. New Haven, CT: Yale University Press.

Nussbaum, Martha C. 1998. "Whether from Reason or Prejudice": Taking Money for Bodily Services. Journal of Legal Studies 27 (2): 693-724.

Posner, Richard A. 1992. Sex and Reason. Cambridge, MA: Harvard University Press.

Query, Julia, John Montoya, and Vicky Funari. 2000. Live Nude Girls Unite! DVD, written and directed by Julie Query and Vicky Funari. Brooklyn, NY: First Run/Icarus Films.

Radin, Margaret Jane. 1987. Market Inalienability. Harvard Law Review 100:1849-937.

—. 1996. Contested Commodities. Cambridge, MA: Harvard University Press. 
Rao, Radhika. 2000. Property, Privacy, and the Human Body. Boston University Law Review 80 (2): 359-460.

- 2007. Genes and Spleens: Property, Contract or Privacy Rights in the Human Body? Journal of Law, Medicine and Ethics 35:371-80.

Rodrigues, Janette. 2005. Coca-Collector. Virginian-Pilot, June 1, E4.

Rose, Carol M. 1992. Giving, Trading, Thieving, Trusting. Florida Law Review 44:295-317.

—. 1994. Rhetoric and Romance: A Comment on Spouses and Strangers. Georgetown Law Journal 82 (7): 2409-21.

Sandel, Michael J. 1998. What Money Can't Buy: The Moral Limits of Markets. Reprinted in Rethinking Commodification: Cases and Readings in Law and Culture, ed. Martha M. Ertman and Joan C. Williams, 122-27. New York: New York University Press.

- 2007. The Case Against Perfection: Ethics in the Age of Genetic Engineering. Cambridge, MA: Belknap Press.

Sanger, Carol. 2007. Developing Markets in Baby Making: In the Matter of Baby M. Harvard Journal of Law $\mathbb{B}$ Gender 30 (1): 67-97.

Siegel, Reva B. 1994. The Modernization of Marital Status Law: Adjudicating Wives' Right to Earnings, 1860-1930. Georgetown Law Journal 82 (7): 2127-211.

Silbaugh, Katharine. 1997. Commodification of Women's Household Labor. Yale Journal of Law E Feminism 9:81-121.

Skloot, Rebecca. 2006. Taking the Least of You. New York Times Magazine, April 16, 38.

Staudt, Nancy C. 1996. Taxing Housework. Georgetown Law Journal 84 (5): 1571-647.

Stone, Deborah A. 1999. Beyond Moral Hazard: Insurance as Moral Opportunity. Connecticut Insurance Law Journal 6 (1): 11-46.

Sunstein, Cass A. 1997. Free Markets and Social Justice. New York: Oxford University Press.

Williams, Joan. 2000. Unbending Gender: Why Family and Work Conflict and What to Do About It. New York: Oxford University Press.

Williams, Joan C., and Viviana A. Zelizer. 2005. To Commodify or Not to Commodify: That Is Not the Question. In Rethinking Commodification: Cases and Readings in Law and Culture, ed. Martha M. Ertman and Joan C. Williams, 362-82. New York: New York University Press.

Zelizer, Viviana A. 1979. Morals and Markets: The Development of Life Insurance in the United States. New York: Columbia University Press.

—. 1985. Pricing the Priceless Child: The Changing Social Value of Children. New York: Basic Books. 1994. The Social Meaning of Money. New York: Basic Books. 2000. The Purchase of Intimacy. Law $\mathcal{E}$ Social Inquiry 25 (1): 817-42. 2005. The Purchase of Intimacy. Princeton, NJ: Princeton University Press.

\section{CASES CITED}

Borelli v. Brusseau, 16 Cal. Rptr. 2d 16 (Ct. App. 1993).

Greenberg v. Miami Children's Hospital, 264 F. Supp. 2d 1064 (S.D. Fla. 2003).

In re Baby M, 537 A.2d 1227 (N.J. 1988).

Marvin v. Marvin, 557 P.2d 106 (Cal. 1976).

Moore v. Regents of the University of California, 793 P.2d 479 (Cal. 1990).

Smith v. Knoller, No. 319532 (Cal. Super. Ct. Aug. 9, 2001). 